\title{
A Brief Summary of the Water Bill, SB 552 ${ }^{1}$
}

\author{
Lisa Krimsky, Andrea Albertin, Charles Barrett, James Fletcher, and Mary Lusk²
}

Florida Senate Bill 552 was passed in 2016 to protect Florida's water and natural resources. The policies aim to preserve and restore the state's resources for current and future use. This document is intended to act as a quick reference guide and is not inclusive of all measures in SB 552. This summary addresses the Florida Springs and Aquifer Protection Act, the Central Florida Water Initiative, Northern Everglades and Estuaries Protection, and Pilot Programs for Alternative Water Supply. For additional information, refer to Handbook of Florida Water Regulation: Florida Water Bill.

\section{The Florida Springs and Aquifer Protection Act}

Created by the 2016 Florida Water Bill, its aim is to protect and restore flows and water quality in the state's Outstanding Florida Springs (OFS), which are defined as the 33 first-magnitude springs in the state as well as 6 secondmagnitude springs (Figure 1). This legislation:

- Gives the Florida Department of Environmental Protection (FDEP) authority to initiate emergency rulemaking if the water management districts fail to adopt minimum flows and minimum water levels for all OFS by July 2017 (2026 for Northwest Florida Water Management District).

- Requires immediate adoption by FDEP or water management districts (WMD) of a recovery strategy if an OFS is found to fall below the minimum flows and minimum water levels threshold; these recovery strategies must target achieving the minimum flows and minimum water levels within 20 years.

- Designates that FDEP must delineate a priority focus area (PFA) for each OFS; these PFAs are areas of the springshed where the aquifer is deemed especially vulnerable to pollutant inputs because of factors such as: hydrogeology, groundwater residence time, nutrient loading, anthropogenic disturbances, etc.

- All local governments within a PFA must adopt an urban fertilizer ordinance, at a minimum the Model Ordinance for Florida-Friendly Fertilizer Use on Urban Landscapes.

- There are several prohibited activities within a PFA; these include:

- Construction of new domestic wastewater treatment facilities that do not treat to at least a $3 \mathrm{mg} / \mathrm{L}$ level for nitrogen

- Installation of onsite sewage treatment and disposal systems on lots less than 1 acre, if the addition of the specific systems conflicts with an onsite treatment and disposal system remediation plan incorporated into a basin management action plan

- New hazardous waste disposal facilities

- Land application of wastewater biosolids, unless in accordance with an FDEP-approved plan

- Agricultural operations that do not implement best management practices (Ag-BMPs) or initiate and carry out a water monitoring regime

1. This document is FA205, one of a series of the Program in Fisheries and Aquatic Sciences of the School of Forest Resources and Conservation, UF/IFAS Extension. Original publication date May 2018. Visit the EDIS website at http://edis.ifas.ufl.edu.

2. Lisa Krimsky UF/IFAS Extension Florida Sea Grant Water Resources Regional Specialized Agent III, Southeast District; Andrea Albertin UF/IFAS Water Resources Regional Specialized Agent II, Northwest District; Charles Barrett, UF/IFAS Water Resources Regional Specialized Agent II, Northeast District; James Fletcher, UF/IFAS Water Resources Regional Specialized Agent IV, Central District; and Mary Lusk, UF/IFAS Water Resources Regional Specialized Agent II, Southwest District; UF/IFAS Extension, Gainesville, FL 32611.

The Institute of Food and Agricultural Sciences (IFAS) is an Equal Opportunity Institution authorized to provide research, educational information and other services only to individuals and institutions that function with non-discrimination with respect to race, creed, color, religion, age, disability, sex, sexual orientation, marital status, national origin, political opinions or affiliations. For more information on obtaining other UF/IFAS Extension publications, contact your county's UF/IFAS Extension office. 


\section{Outstanding Florida Springs}
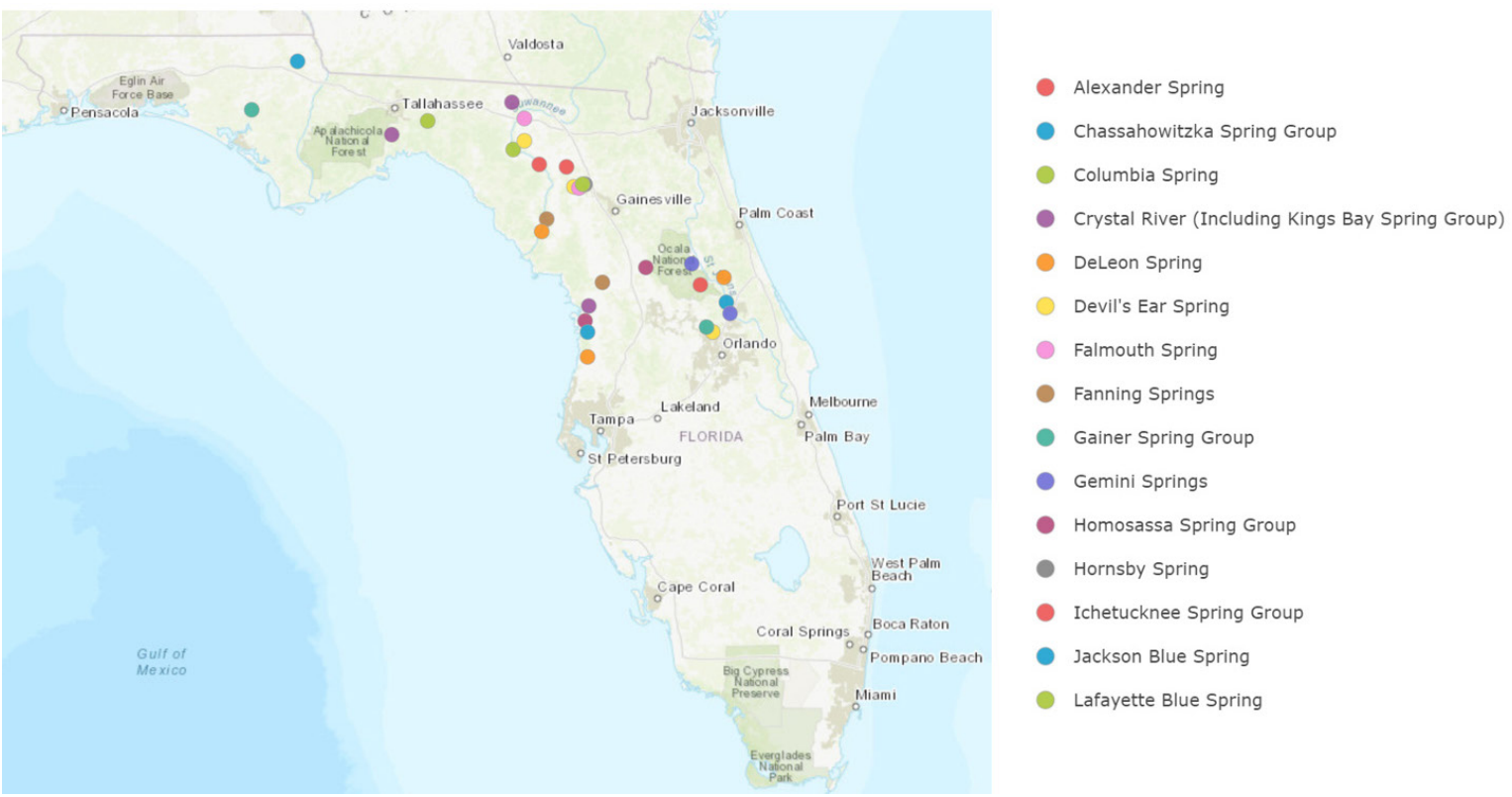

- Madison Blue Spring

Manatee Spring

Peacock Springs

Poe Spring

Rainbow Spring Group

Rock Springs

Silver Glen Springs

Silver Springs

- Treehouse Spring

- Troy Spring

- Volusia Blue Spring

- Wacissa Spring Group

- Wakulla Spring

Weeki Wachee Spring Group

Wekiwa Spring

Figure 1. Map of Florida's Outstanding Florida Springs.

Credits: Mary Lusk, UF/IFAS; Source: FDEP

- Requires assessment of all OFS for nutrient impairments and the development of a Total Maximum Daily Load (TMDL) and Basin Management Action Plan (BMAP) whenever impairments are found; TMDL goals must be met within 20 years of BMAP adoption.

- If, during TMDL and BMAP development, onsite wastewater treatment and disposal systems (septic systems) are found to contribute at least 20 percent of non-point source nitrogen pollution, then local governments within the springshed must adopt a remediation plan to address this source of nitrogen loading. These remediation plans may include conversion to central sewer or replacement/ remediation of conventional septic tank systems with advanced N-removal technology.

For more information on the Florida Springs and Aquifer Protection Act, refer to Handbook of Florida Water Regulation: Florida Springs and Aquifer Protection Act.

\section{The Central Florida Water Initiative}

The Central Florida Water Initiative (CFWI) was codified into law in 2016. The designation "Central Florida Water Initiative Area”, or CFWI area, includes all of Orange, Osceola, Polk, and Seminole Counties, as well as southern Lake County (Figure 2). Over the past decade, the St. Johns River Water Management District (SJRWMD), the South Florida Water Management District (SFWMD), the Southwest Florida Water Management District (SWFWMD), and the Florida Department of Environmental Protection
(FDEP) have determined that the Floridan Aquifer system is locally approaching the sustainable limits of use. Together, they are exploring conservation and alternative water supply (AWS) measures to meet the long-term water needs of the area. For more information on CFWI, please visit Collaborative Planning for the Future of Water Resources in Central Florida: Central Florida Water Initiative.

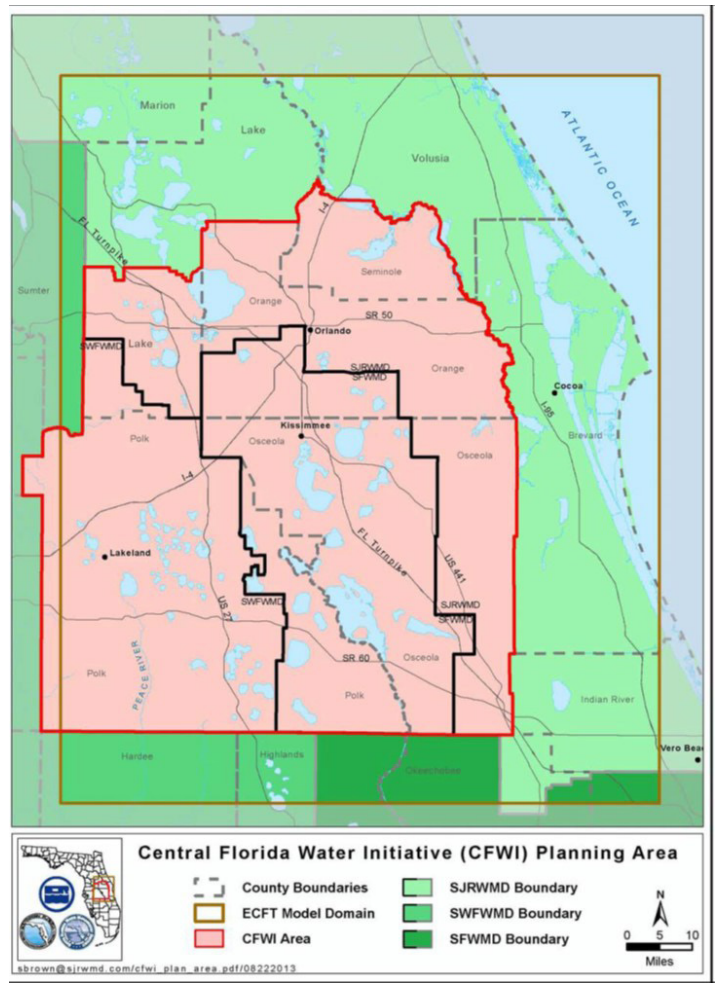

Figure 2. Map of Central Florida Water Initiative (CFWI) Planning Area. Credits: CFWI (2015) 
This new law requires the development and implementation of a single multidistrict regional water supply plan including any needed recovery or prevention strategies, a list of water supply development projects, and a list of water resource development projects. It also requires the development of a single hydrologic planning model to assess the availability of groundwater in the CFWI area.

The CFWI will develop a water supply planning program that:

- Considers limitations on groundwater use together with opportunities for new, increased, or redistributed groundwater uses

- Establishes a coordinated process for the identification of water resources requiring new or revised conditions

- Considers existing recovery or prevention strategies

- Includes a list of water supply options sufficient to meet the water needs of all existing and future reasonablebeneficial uses

- Identifies, as necessary, which of the water supply sources are preferred.

In addition, FDEP along with the help of the three WMD and the Florida Department of Agriculture and Consumer Services (FDACS) shall adopt uniform rules for application within the CFWI area that include:

- A single, uniform definition of the term "harmful to the water resources"

- A single method for calculating residential per capita water use

- A single process for permit reviews

- A single, consistent process, as appropriate, to set minimum flows and minimum water levels and water reservations

- A goal for residential per capita water use for each consumptive use permit

- An annual conservation goal for each consumptive use permit consistent with the regional water supply plan

\section{Northern Everglades and Estuaries Protection Program}

Florida Senate Bill 552 (2016) updates the Northern Everglade and Estuaries Protection Program (NEEPP) to incorporate the BMAPs for Lake Okeechobee, the Caloosahatchee River and Estuary, and the St. Lucie River and Estuary, as well as FDACS's implementation of best management practices (BMPs). NEEPP is a comprehensive watershed approach to improving the quality, quantity, timing and distribution of water in the Northern Everglades ecosystem (Figure 3). It includes the Lake Okeechobee, Caloosahatchee River, and St. Lucie River Watershed Protection Programs. For more information on NEEPP, please visit Handbook of Florida Water Regulation: Northern Everglades and Estuaries Protection Program.

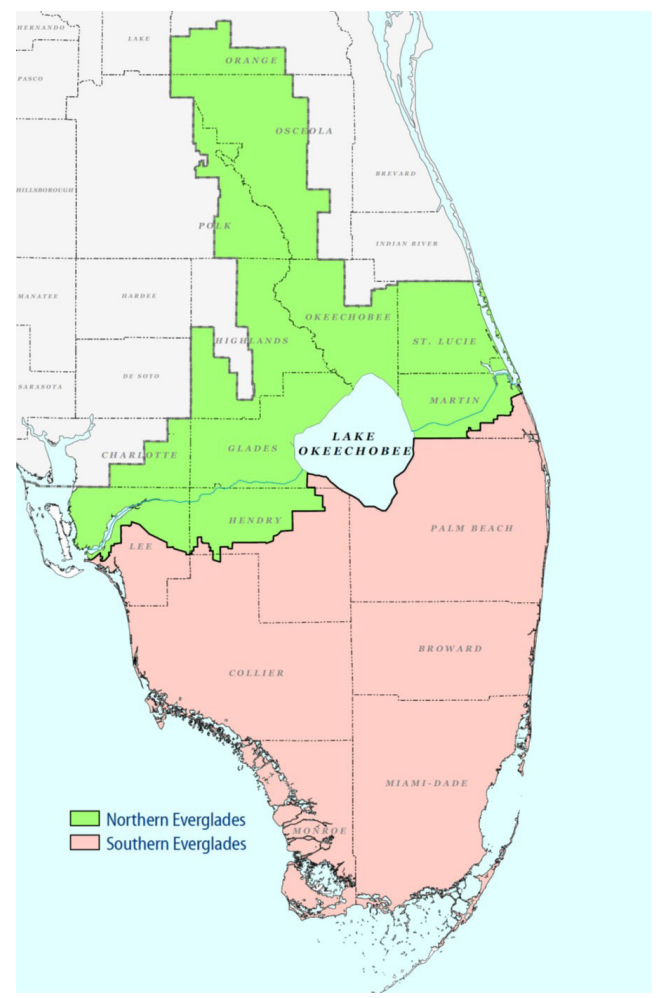

Figure 3. Everglades Ecosystem Map.

Credits: SFWMD

\section{Lake Okeechobee Watershed Protection Program}

Addresses the reduction of phosphorus loading to the lake from both internal and external sources through a phased program of implementation. Consists of individual measures that are re-evaluated and updated every 5 years:

- The Lake Okeechobee Watershed Protection Plan

- Identifies the geographic extent of the watershed

- Contains an implementation schedule for phosphorus reduction

- The Lake Okeechobee Watershed Construction Project

- Phase I and II Technical Plans

- Includes measures for the improvement of the hydrology and water quality of Lake Okeechobee and downstream receiving waters, including the Caloosahatchee and St. Lucie Rivers and Estuaries 
- The Lake Okeechobee Watershed Research and Water Quality Monitoring Program

- Evaluates water quality data and develops a baseline for total phosphorus

- Assesses water volumes, timing, and current water management practices

- Assesses sources of phosphorus and develops a water quality model

- Evaluates the feasibility of alternative nutrient reduction technologies

- The Lake Okeechobee Basin Management Action Plan

- Designed to achieve the TMDL by improving the management of phosphorus sources within the watershed

- Must include milestones for implementation and water quality improvement and a monitoring program capable of evaluating these milestones

- TMDL goals must be met within 20 years of BMAP adoption

- The Lake Okeechobee Exotic Species Control Program

- Identifies exotic species and develops and implements measures to protect the native flora and fauna within the watershed

- The Lake Okeechobee Internal Phosphorus Management Program

- Evaluates the feasibility of phosphorus load removal projects

\section{The Caloosahatchee and St. Lucie River Watershed Protection Program}

Protects and restores surface water resources by addressing the reduction of pollutant loadings based upon adopted TMDLs, the restoration of natural hydrology, and compliance with applicable state water quality standards. Both Watershed Protection Plans are achieved through a phased implementation program and consist of:

- A Watershed Protection Plan

- Watershed Research and Water Quality Monitoring Program

- Watershed BMAPs

\section{Pilot Programs for Alternative Water Supply}

The Water Bill creates a pilot program for alternative water supply projects in restricted allocation areas. These are areas where existing water sources are not enough to meet current or projected future demand and sustain water resources and natural systems.

Alternative water supplies are nontraditional water sources in a water supply planning region. They can include:

- Saltwater

- Brackish surface or groundwater

- Reclaimed water (highly treated wastewater)

- Water made available through new surface or groundwater storage, and

- Stormwater from rainfall

The bill recognizes that it is hard to secure funds to develop alternative water supplies. Therefore, it allows the SFWMD, the SWFWMD and the SJWMD to designate and implement one pilot alternative water supply development project in a restricted allocation area.

- The WMDs can partner with other entities, including self-suppliers, on these projects, and they can provide up to $50 \%$ funding assistance.

- Each project has to show that it provides both water supply and environmental benefits.

\section{Additional Implications for Agriculture}

- Consumptive use permits cannot be reduced on farms that use BMPs or other water saving techniques to conserve water or where water was conserved as a result of weather events, crop disease, market conditions, nursery stock availability, or changes in crop type. This condition applies for the length of time for which the permit is given (during the terms of the permit; the permit maybe revised when the holder re-applies).

- Priority consideration will be given to public-private partnerships on agricultural lands that:

- store or treat water to enhance hydrologic improvements, water quality or increase water supply

- provide critical groundwater recharge

- provide changes in land-use that reduce nutrient loading and maximize water conservation 
- No new agricultural operations are permitted in Priority Focus Areas of Outstanding Florida Springs unless they implement BMPs or have groundwater monitoring plans.

- FDEP, FDACS, and UF/IFAS shall cooperate in conducting research and demonstration projects to develop improved or additional nutrient management tools that can be used by producers as BMPs.

- FDACS shall study new or revised agricultural BMPs for improving and protecting OFS, and, if necessary, in cooperation with applicable local governments and stakeholders, initiate rulemaking to require the implementation of such practices within a reasonable period.

- FDACS, with consultation of WMDs and FDEP, has developed procedures to verify implementation of agriculture interim measures and BMPs, including enforcement procedures applicable to the landowner, discharger, or other responsible person because of noncompliance.

\section{References}

Chapter 259, Florida Statutes

Chapter 373, Florida Statutes

Chapter 403, Florida Statutes

The Florida Senate. CS/CS/SB 552: Environmental Resources. Accessed January 18, 2018. https://www.flsenate. gov/Session/Bill/2016/0552

Florida Department of Environmental Protection (FDEP) Geospatial Open Data. Accessed 2017. http://geodata.dep. state.fl.us/datasets/outstanding-florida-springs-ofs

Central Florida Water Initiative (CFWI). 2015. Regional Water Supply Plan: 2035 Water Resources Protection and Water Supply Strategies. Retrieved from: http://cfwiwater. com/pdfs/plans/WRP_VolII_Final_2015-12-16.pdf

South Florida Water Management District (SFWMD). Northern Everglades and Estuaries Protection Program. Accessed January 18, 2018. https://www.sfwmd.gov/ our-work/northern-everglades 